University of Nebraska - Lincoln

DigitalCommons@University of Nebraska - Lincoln

Alan Tomkins Publications

Public Policy Center, University of Nebraska

2008

Constructs of Justice: Beyond Civil Litigation

\author{
Alan Tomkins \\ University of Nebraska-Lincoln, atomkins@nebraska.edu \\ Kimberly Applequist \\ University of Nebraska-Lincoln
}

Follow this and additional works at: https://digitalcommons.unl.edu/publicpolicytomkins

Part of the Public Policy Commons

Tomkins, Alan and Applequist, Kimberly, "Constructs of Justice: Beyond Civil Litigation" (2008). Alan Tomkins Publications. 17.

https://digitalcommons.unl.edu/publicpolicytomkins/17

This Article is brought to you for free and open access by the Public Policy Center, University of Nebraska at DigitalCommons@University of Nebraska - Lincoln. It has been accepted for inclusion in Alan Tomkins Publications by an authorized administrator of DigitalCommons@University of Nebraska - Lincoln. 


\title{
Constructs of Justice: Beyond Civil Litigation
}

\author{
Alan J. Tomkins and Kimberly Applequist
}

$\mathrm{I}$

$\mathrm{t}$ is the case that civil justice problems constitute the bulk of courts' work in both the state and federal legal systems (see, e.g., Court Statistics Project, 2006; U.S. Courts, 2007). Nevertheless, a decision rendered by a jury (or a judge) takes place in only a relatively small percentage of civil disputes. There are exponentially more civil disputes resolved outside of court than are resolved via jury verdicts (see, e.g., Galanter, 1983, 1993, 1996; Miller \& Sarat, 1980-1981; Trubek, Grossman, Felstiner, Kritzer, \& Sarat, 1983), a state of affairs true for the UK as well as the US (Pleasence, 2006). Hersch's (2006) analysis of nearly 3,800 federal civil cases shows even a litigant's request for a jury trial rather than a bench trial (regardless of whether it emanates from the plaintiff or the defendant) in trial-eligible cases is more likely to result in the parties' out-of-court settlement than it is to result in a jury verdict.

The empirical reality, thus, is that juries play only a limited-it is fair to say, a relatively minor - role in civil dispute resolution. Yet jury research has dominated the scholarship of the psychology and law community virtually since the revival of psycholegal research in the 1970s, and the pattern of focusing on jury matters continues today. This chapter is a call for psycholegal scholars to study civil justice matters beyond the context of litigation and the courts, both to allow us to better understand the resolution of civil issues in the litigation/court contexts and to better understand the larger institutional (and sometimes societal) contexts in which civil disputes materialize and are most often resolved (see Felstiner, Abel, \& Sarat, 1980-1981; Galanter, 1983, 1993, 1996; Kritzer, Vidmar, \& Bogart, 1991; Trubek et al., 1984; Trubek, Sarat, Felstiner, Kritzer, \& Grossman, 1983).

An area of psycholegal research that has provided significant insights into civil disputes is the different conceptualizations of "justice." Over the last fifty

Correspondence - A. J. Tomkins, Public Policy Center, University of Nebraska-Lincoln, 121 S. 13th St., Suite 303, Lincoln, NE 68588-0228; email atomkins2@unl.edu 
years or so, there has been a great deal of commentary and research into various psychosocial constructs of justice. In this chapter we focus on the more prominent justice theories, that is, distributive, procedural, restorative, and retributive justice (e.g., Tyler, Boeckmann, Smith, \& Huo, 1997). ${ }^{1}$

Briefly, distributive justice is concerned primarily with the perceived fairness of the outcome of a given proceeding, whether that proceeding is judicial, quasi-judicial (e.g., arbitration, mediation, or some other form of dispute resolution), or entirely non-judicial in nature (e.g., legislative decisions that affect distribution of resources). Procedural justice, in contrast, is concerned with whether the procedures used in a given process are considered fair by the participants, and is similarly not restricted to judicial settings. Restorative justice is concerned, as the name implies, with restoring an injured party to his or her pre-injury state and helping the injuring party recognize and redress the injurious nature of his or her acts. Finally, retributive justice looks at the psychology of responding to harms that have been inflicted. Recent research indicates that retributive and restorative justice principles are, as with the distributive and procedural justice contexts, applicable outside the judicial context (e.g., Morrison \& Ahmed, 2006).

More thorough reviews of justice concepts are offered elsewhere in this volume (see, e.g., Greene's chapter on therapeutic and restorative justice and Robbennolt's chapter on apologies; for particularly useful analyses of the psychological dimensions of justice, see the scholarship of Tom Tyler-e.g., Lind \& Tyler, 1988; Tyler, 1994b; Tyler et al., 1997). In this chapter, we will briefly discuss justice constructs and offer examples of important questions outside the courtroom litigation realm that we believe present opportunities for psycholegal scholars to more fully develop our understanding of civil justice.

\section{Distributive Justice}

Early research into theories of justice focused primarily upon the perceived fairness of the outcome of a dispute or allocation process as the primary factor influencing a party's satisfaction with the proceedings. This focus evolved from the notion that people would primarily be concerned with the fairness of the outcomes they received (or were burdened with), though thinking of distributive justice as merely defined by "what's in it for me" would be missing the point. Rather, it is more accurate to characterize distributive justice as being primarily

1 There is some disagreement about whether additional justice constructs ought to be included among the "prominent" justice theories. For example, Weinrib (2002) writes about corrective justice, referring to "the idea that liability rectifies the injustice inflicted by one person on another" (p. 349). There are even disagreements about the precise taxonomy of the various justice constructs as well as the numbers, their boundaries, etc. For purposes of this chapter, we rely on the constructs of justice used by Tom Tyler, by far the most prolific and important of modern justice scholars, and his colleagues in their book, Social Justice in a Diverse Society (1997). 
concerned with the appropriate distribution of costs and benefits within a society, and the principles that people believe ought to influence and determine such distributions.

Deutsch (1985) points out that although the concept of distributive justice is quite old, going back at least as far as Aristotle, theoretical and experimental social psychology only began to seriously consider justice issues about a half-century ago as an extension of equity theory (e.g., Adams, 1965; Thibaut \& Kelley, 1959; see generally, Lerner, 1975; Lerner \& Lerner, 1981; Walster, Walster, \& Berscheid, 1978). In the past few decades, distributive justice has been studied frequently in the context of the legal system. Although manifestly applicable in litigation contexts (who wins, who loses, and how do the parties feel about the fairness of the outcomes?), it is equally relevant to the allocation of resources in other societal contexts as well, ranging from political theory and policy to education, business and other similar areas.

John Rawls, a philosopher, has developed some of the most influential ideas about distributive justice. In his 1971 treatise, A Theory of Justice, Rawls explored principles of justice using the concept of a "veil of ignorance." According to Rawls, the fairest principles that could be chosen for a society would be the ones its members would choose if it were not possible for them to know in advance what role they would occupy within that society (Hegtvedt \& Cook, 2001). Such principles, Rawls theorized, would focus on "impartial behavior and fairness in the distribution of social benefits and burdens" (Michelbach, Scott, Matland, \& Bornstein, 2003, p. 523) - thus the term distributive justice.

There are several principles that influence opinions about what constitutes fairness of outcome, and they may have different relative importance depending upon the situation in question and the parties involved. Michelbach et al. (2003) identify four key allocation concepts that consistently appear in the research literature: "equality, efficiency, need, and merit" (p. 524, emphasis in original), although some authors focus on only three principles: equity (roughly the equivalent of efficiency as described by Michelbach et al., below), equality and need (e.g., Hegtvedt \& Cook, 2001). All four concepts noted by Michelbach et al. are specifically identified in Rawls' early work. Equality has been defined in a number of ways, and there is significant disagreement regarding what, exactly, it means. Definitions vary from "absolute equality of income" (Michelbach et al., p. 524, citing Rawls, 1971) to more general conceptualizations like equality of opportunity or similar compensation for similar levels of effort. Efficiency (or equity) constitutes a departure from absolute equality to an unequal distribution of resources motivated by increased overall productivity (Michelbach et al., p. 524). Need refers, as the name implies, to access (or lack thereof) to the essentials of life, and merit (sometimes called desert or proportionality) refers to inherent qualities like intelligence, beauty, and willingness to work hard (Michelbach et al., pp. 524-525). Interestingly, Rawls and others argue merit should not be a basis for distribution of resources, though many others disagree (Michelbach et al., p. 525).

These four concepts, applied individually, might well lead to different outcomes in any given situation. For example, equality might require an even dis- 
tribution of resources among competing parties, while a need-based allocation might result in a previously disadvantaged party receiving a larger share of the resources, and an efficiency-based allocation might call for distributing a larger share to those parties that produce the most. In a given situation, then, how might one decide which principle(s) should be applied to make an appropriate allocation determination? There is, perhaps not surprisingly, some dispute about this. Rawls himself felt that the principles apply in some sort of orderly hierarchy, but others have argued that people may use most or all of the principles to some degree, depending on the given situation (Scott, Matland, Michelbach, \& Bornstein, 2001). Research in the area of distributive justice also suggests that there may be differences in priority for people of different demographic groups. Gender, race/ ethnicity, and cultural background can all affect distribution prioritization (Michelbach et al., 2003; Scott et al., 2001), as can cognitive processes such as attributions (Hegtvedt \& Cook, 2001).

Given the principles that appear to be at work in the distributive justice construct, then, it is not difficult to see how research in this area could tell us much not only about civil justice in courtroom settings, but also about legislative decisions that regulate courtroom outcomes (e.g., should there be caps placed on medical malpractice awards?) or allocate resources directly (e.g., through regulations or restrictions that limit agricultural water use to protect the water rights of downstream water users). Distributive justice principles would be particularly valuable to examine public satisfaction with administrative agency decision-making, which regulates so much activity in American society, particularly with respect to the allocation or distribution of resources (e.g., Helm, 2001; Rubin, 2005; Suk, 2006).

\section{Procedural Justice}

Perhaps somewhat surprisingly, distributive justice principles are often less important to disputants than other factors when individuals are asked to evaluate their overall satisfaction with the resolution of some dispute or resource allocation. In many instances, procedural justice principles carry greater weight than distributive outcome measures like equity or equality in determining the overall level of satisfaction for parties to a dispute. In other words, individuals who view the dispute resolution process (whether that process involves a criminal or civil trial, arbitration or mediation, or some less formal dispute resolution mechanism) as fair are often more willing to accept outcomes that are objectively less equal or equitable.

Starting with early research by John Thibaut, a social psychologist, and Laurens Walker, a law professor, into procedural justice, the role of perceptions of procedural justice has been and continues to be a major focus for psycholegal researchers (Thibaut \& Walker, 1975, 1978; see generally, Lind \& Tyler, 1988; Tyler \& Lind, 2001). Indeed, research into the interactive roles of procedural and distributive justice indicates that a sense of procedural justice is usually more impor- 
tant than a sense of distributive justice in determining whether an outcome or distribution allocation is likely to be accepted by the parties to a dispute (Tyler, 2000; Tyler et al., 1997).

Procedural justice, as the name implies, focuses on whether the procedures used to make an allocation determination are fair, without regard to the actual outcome. Tyler (1991) identifies four key factors that individuals weigh when determining whether a proceeding is procedurally fair: fairness and neutrality of the decision maker; opportunity to present one's side of the dispute (also called voice); trustworthiness (as opposed to mere neutrality) of the decision maker; and respectful treatment of all parties during the course of the proceedings.

Perhaps least surprising among the four components of procedural justice is the requirement that the decision maker be perceived as neutral. Although it might seem reasonable that one would prefer to have a dispute heard by a judge known to be biased in favor of the claimant's position, ${ }^{2}$ it is also the case that no one would want to have a matter resolved by a decision maker known to be biased against the claimant. Thus, it is important that the decision maker be perceived as neutral by all parties to a dispute in order to prevent either party from feeling that justice has suffered due to the decision maker's bias.

As important as the neutrality of the decision maker is the opportunity to present one's side of the dispute in front of that neutral decision maker. Research indicates that the opportunity to voice one's position is critical to the overall perception of procedural justice. Indeed, there are reports of instances where even though a party has received everything sought in a dispute, he or she nevertheless reports frustration with the proceedings due to the denial of the opportunity to fully tell his or her story. Tyler (1988) reports defendants' dissatisfaction with a traffic court judge who routinely dismissed the tickets of those who appeared in court to contest them. The judge reasoned that if the defendants had taken the time off their jobs to come to court to fight the matter, they had been sufficiently punished for whatever infraction they might have been charged with. Although the outcome manifestly favored those who contested their traffic tickets, the defendants frequently reported that they felt frustrated with the outcome because they were not given the opportunity to present their case before the decision was rendered. Many of them had gone to some lengths to prepare their case-taking pictures of the scene or arranging witnesses - only to have all charges dropped before they could tell their side of the story. Despite the positive distributive outcome, they were disturbed by the fact that their voice was not heard.

Related but not identical to the neutrality of the decision maker is his, her, or their trustworthiness. A biased decision maker by definition will not be deemed trustworthy by all parties to a dispute, but neutrality does not guarantee trust-

2 Indeed, this common sentiment is the inspiration behind a t-shirt that is popular among litigators, which reads, "A good lawyer knows the law; a great lawyer knows the judge." 
worthiness. Rather, the decision maker must be an individual or group whom the parties believe will apply any relevant laws, rules, or other decision-making principles in an appropriate and consistent manner to oversee the proceedings and arrive at his, her, or their decision(s). Trustworthiness also has implications for legitimacy in governmental actions (Tyler, 2000; Tyler et al., 1997; see generally, Cross, 2005).

Respectful treatment is at least partially related to, yet distinct from, the other factors that comprise procedural justice. Giving the parties the opportunity to voice their concerns and stories can indicate respect for the parties. Similarly, an open display of neutrality can convey the message that one has sufficient respect for all parties to withhold judgment until the facts of the matter have been heard. Yet respectful treatment also includes such simple factors as courteous treatment and an absence of sarcasm or harsh or inappropriate criticism over the course of dispute resolution proceedings.

Often, the presence of sufficient evidence of procedural justice can overcome a lack of distributive justice in the outcome of a given proceedings, leaving losing participants nevertheless willing to accept the outcome of the process (e.g., Lind \& Tyler, 1988). Interestingly, perceptions of a lack of procedural justice can cause parties to be dissatisfied with a proceeding even when the outcome of the proceeding is in their favor. Tyler's example of the traffic court judge cited previously is just one example of this paradoxical effect.

The potency of procedural justice constructs for understanding participant perceptions in civil disputes goes beyond litigation contexts. For example, Markell (2006) argues that procedural justice provides a framework that allows researchers and others to anticipate and understand citizen satisfaction with and attributions of legitimacy to international administrative actions in environmental policymaking and decision-making domains under the North American Free Trade Agreement (NAFTA). Procedural justice also makes a difference in participant perceptions in such civil justice areas as commitment hearings (Tyler, 1992), affirmative action (Tyler, 2004), and compliance with intellectual property laws (Tyler, 1997a). Sunshine and Tyler (2003) show that procedural justice principles help confer legitimacy upon government actions, in this instance the legitimacy of the police in New York (see generally, Hibbing \& Theiss-Morse, 2001; Tyler, 1997b, 2006, 2007; Tyler \& Darley, 2000).

\section{Retributive and Restorative Justice}

Retributive justice is focused on whether there should be sanctions for those who break rules; if sanctions are imposed, which ones are appropriate in light of the circumstances; and how severe the sanctions imposed should be (e.g., Tyler, Boeckmann, Smith \& Huo, 1997; Tyler et al., 1997, chap. 5). Sanctions can include compensation to one's victim as well as punishment of the transgressor as a 
means of restoring that which has been disrupted by a dispute, rule-breaking, or other transgression (e.g., Brickman, 1977; Shultz \& Darley, 1991).

The concept and theory of restorative justice, sometimes alternatively described as therapeutic justice or victim-offender mediation, is relatively new, though many of the procedures it generally utilizes are actually quite old. It has gained significant popularity in the context of relatively minor crimes, particularly when such crimes are committed by youthful offenders. Restorative justice generally involves bringing the victim of the crime (or other injury) and/or his or her family together with the offender (and perhaps the offender's family or other community members, depending upon the age of the offender and the nature of the offense). The parties meet in a supportive setting that allows the victim to express how he or she has been affected by the offender's acts and be involved in determining appropriate punishment or restitution, and allows the offender to be held directly accountable to his or her victim (Umbreit \& Ritter, 2006). The hope of restorative justice proponents is that such proceedings ultimately produce greater satisfaction among all the parties involved than traditional judicial proceedings would, and that they will decrease the likelihood of future wrongdoing by the offender.

The restorative justice movement arose in response to traditional criminal justice methods, which historically focused on determining whether an offender has violated a statute and meting out appropriate punishment for such a violation, usually in the form of incarceration or fines, without regard to whether such proceedings were adequate to help make the victim(s) of the offender's crimes whole again. Indeed, as noted by Umbreit, Vos, Coates, and Lightfoot (2006):

Most contemporary criminal justice systems focus on law violation, the need to hold offenders accountable and punish them, and other state interests. Actual crime victims are quite subsidiary to the process and generally have no legal standing in the proceedings. Crime is viewed as having been committed against the state, which, therefore, essentially owns the conflict and determines how to respond to it. The resulting criminal justice system is almost entirely offender driven (p. 253).

The process is thus often highly unsatisfactory to the offender's victims, who may feel ignored or undervalued by the process, as if they were merely bystanders to the process of justice. It may also produce less than ideal results for offenders by focusing on punishment rather than healing the damage they caused, denying them the opportunity to understand the ramifications of and make restitution for their past actions (Gray-Kanatiiosh \& Lauderdale, 2006; Roche, 2006).

As part of their in-depth analysis of a restorative justice dialogue that arose from the robbing of an Israeli woman by two Palestinian boys, Umbreit and Ritter (2006) articulate six elements to a restorative justice dialogue. First, everyone who was directly affected by the crime should be encouraged to participate in 
the dialogue. Second, the victim and the offender should be able to choose family members and/or support persons to be present, if they desire.

Third, critically, participation in the dialogue must be voluntary by all parties. Fourth, the process of the dialogue should be adapted to the needs of both the victim and the offender. Fifth, extra deference should be shown to the victim, but the offender should still be treated with respect. And sixth, all of the primary parties to the dialogue should be prepared in advance through in-person meetings with some mediator/facilitator prior to the dialogue.

While the concept of restorative justice is relatively new to American courts, similar principles can be found in many traditional or historical societies. GrayKanatiiosh and Lauderdale (2006) discuss the use of restorative principles in Native American societies as a way of maintaining balance within the society. They argue that, rather than exerting control through "stricter laws, more law enforcement officers, and increased funding" as a way to decrease crime in Native American communities, the money would be better spent restoring "a multidimensional 'web of justice' by identifying, understanding and, where possible, re-creating traditional cultural social practices and structures to maintain social balance, diversity, and harmony within their societies" (pp. 29-30). The "web of justice" they describe includes "preventative as well as restorative mechanisms that together function to maintain justice, at least justice as fairness" (p. 30, emphasis added).

More recent research in the area of restorative justice has expanded from the criminal law context to applying the principles of restorative justice in other areas (e.g., Tyler, 2006; see generally, Morrison \& Ahmed, 2006). One such area is that of civil litigation. Civil litigation, and more particularly tort litigation, is generally intended to redress some injury that results from the intentional or negligent acts or omissions of another. Such cases can range from the deliberate injury of one person by another (e.g., battery or libel), to medical malpractice, to the notorious slip-and-fall case (negligence). Similarly, in breach of contract litigation, a party generally alleges that it has been injured due to the other party's failure to perform under the terms of the contract, entitling the non-breaching party to damages or other equitable relief. In both types of lawsuit, the injured party sues in order to be made whole for his or her injury. Yet, is the civil litigation process, with its monetary verdicts, the best recompense for an injury?

Greene's chapter (Ch. 12) in this volume [B. H. Bornstein et al. (eds.), Civil Juries and Civil Justice (Springer, 2008)] is an example of the application of restorative justice in the civil justice arena. As Greene points out, the civil litigation experience can be very unpleasant for all the participants, and can ultimately leave even successful litigants feeling unsatisfied. This lack of satisfaction may stem from a number of factors, including the length of time required for the process, its costs - which include time away from work or loved ones and emotional toll in addition to legal fees and court costs - and various other frustrations.

Greene explores the therapeutic - and especially the counter-therapeutic-effects of litigation. Drawing on procedural justice theory, she argues both plaintiffs 
and defendants in tort litigation may gain some measure of satisfaction from being able to voice their side of the story and from being treated fairly and respectfully. On the other hand, the lengthy and often acrimonious process of litigation, which may stretch out for a considerable period of time and usually results at most in the exchange of monetary compensation, often without the actual dispute being heard by the court (i.e., when the parties settle), may actually have a counter-therapeutic effect in terms of prolonging the suffering of both parties and worsening the physical and mental health and well-being of the injured party (or at least slowing his or her full recovery). It is for these reasons that Greene argues for adoption of a restorative justice approach to tort litigation, as its emphasis is upon speedy resolution to disputes and providing the parties an opportunity to talk through the injury and its impacts and explain their respective sides of the story. The hope is that by encouraging out-of-court resolution, the parties will find it more satisfying and allow them to move past the dispute or incident that led to the initial conflict.

Rather than focusing strictly on restorative justice, Robbennolt in her chapter (Ch. 11) in this volume examines the effects of apologies in a civil litigation context. While apologies can have a therapeutic effect for both an injured party and the wrongdoing party, they are often viewed as counter to the interests of the wrongdoing party, as they may be or appear to be an admission of wrongdoing and responsibility, which may affect the wrongdoing party's financial liability if the matter is brought to trial (i.e., in tort litigation) (see, e.g., Vines, 2007). Robbennolt delves into the research surrounding the practical effects of apologies and the different effects of true apologies that accept responsibility and express remorse versus mere expressions of sympathy, all in terms of an injured party's likelihood of filing a lawsuit or accepting a settlement offer, and in terms of jury perceptions about the wrongdoing party's guilt and financial liability to the injured party. Her work (see especially, Robbennolt, 2003, 2005, 2006) in this regard is admirably thorough and provides helpful guidance for future research into the therapeutic values of apologies and their effects in the dispute resolution process both inside and outside the courtroom.

\section{Justice Principles Outside the Courtroom}

The chapters by Greene and by Robbennolt are examples of psycholegal scholarship that examines justice notions inside the context of courts and litigation and also goes beyond this narrow bandwidth of disputes. Disputes may be resolved, for example, through quasi-legal proceedings such as arbitration or mediation, either by being referred to such proceedings by a court, by virtue of contract provisions requiring that disputes be resolved, at least in the initial stages, through such proceedings, or by the mutual agreement of the parties, who may prefer the speedier and usually less expensive alternatives of arbitration or mediation to formal litigation. In such proceedings, the applicability of the justice constructs described in this chapter are clearly analogous to for- 
mal courtroom proceedings, with arbitration in particular resembling court trials and mediation more closely paralleling the sort of proceeding seen in restorative justice contexts.

In addition, theories of justice may have applicability in areas that seem further outside the dispute resolution process. In ordinary day-to-day affairs, disputes of all sorts arise which may be handled solely by the parties involved or by the parties appealing to some other person to help resolve the dispute. Corporations make internal decisions about resource allocation, among competing programs or internal departments; governmental entities make decisions that affect public health or welfare or require the allocation of resources in a manner that will be accepted by their constituents; health care organizations and insurers make decisions that involve the allocation of scarce healthcare resources, and patients or physicians may seek to appeal those decisions through internal appeal mechanisms within the healthcare organization or health insurer; and friends or family members may argue about any number of decisions and seek help resolving the dispute from therapists or other friends or relatives. The satisfaction of the parties with the outcomes of such disputes may be influenced by the same justice principles seen at work in formal legal proceedings.

For example, in areas such as health care, we can see the application of civil justice principles in an extremely important domain that resides mostly outside of the litigation and courtroom contexts. Extensive research has been done into the applicability of justice principles, particularly procedural and distributive justice, in the health care context. Daniels (2001), for example, relies on distributive and procedural justice principles in his examination of inequities in the healthcare system. Among other things, he concludes that distributive justice principles require protection and maintenance of proper health functioning, in that protection of health also protects the individual's "fair share of the normal range of opportunities (or plans of life) reasonable people would choose in society" (p. 3). However, he argues, since societies have resource constraints, preventing unfettered access to healthcare by all, societies must find a way to meet healthcare needs fairly given such constraints. He argues societies must "rely on a fair process for arriving at solutions to these problems and for establishing the legitimacy of rationing decisions" (p. 9, citing Rawls, 1971). Such procedures should be tied to "deliberative democratic procedures" (p. 9). Also in the healthcare arena, but in contrast to Daniels, Elster (1995) focused on the application of distributive justice principles on allocative decision-making in the context of organ transplantation. At any given time, there are huge numbers of people awaiting organ transplants, yet only a limited number of organs availability for transplantation. Decisions about who should receive organ transplants are constrained or influenced by various factors, including tissue compatibility, likelihood of organ rejection, likely lifespan of a patient if transplantation is successful, and urgency of a given recipient's need or likely level of improvement if the patient receives the transplant. In any given decision, where two recipients might have identical probability of successful transplantation (e.g., equal tissue compatibility and probability of transplant success), giving preference to 
one of the factors over another might lead to a different allocation decision than giving preference to the other factor(s). Often in such situations, doctors will choose to give the transplant to the sicker patient, viewing that patient as having the greater need (thus implicating the distributive justice principle of using need as a determining factor in just allocation decisions), but Elster argued that some measure of consideration should also be given to the likely level of benefit the competing patients would receive, introducing and efficiency component to the distributive justice process of allocation determinations. Furthermore, as Elster notes, often the patient's poor health and need for organ transplantation are "the predictable outcome of earlier behavior" (p. 8). For example, an alcoholic or drug abuser might so damage his or her liver functioning as to require a liver transplant to restore healthy functioning. In such cases, Elster argues, it might be better or more efficient, from a societal perspective, to give preference to a competing patient who requires the transplant due to illness or damage from some prescribed medication, because it provides more incentive for people not to engage in detrimental behaviors if they know that society will not bail them out from the consequences of that behavior.

In addition to his examination of the role of justice principles in the context of organ transplantation, Elster (1995) also reviewed their applicability in the allocation of educational resources, focusing on admission to higher education. Again, this is a form of decision making between competing interests that ordinarily falls outside of the litigation context (barring the occasional lawsuit brought by someone who is denied admission in favor of other objectively similarly-qualified applicants) that implicates distributive and perhaps procedural justice principles. Often college admission decisions are based primarily on merit, which may or may not be one of the distributive justice principles (as discussed elsewhere in this chapter), though frequently some consideration is made with respect to a candidate's relative need, particularly when decisions are made regarding scholarships or other forms of financial support for higher education-again, raising a distributive justice principle. Yet by definition, basing decisions upon merit or need is not providing equality of educational opportunity to all college applicants, bringing the process into conflict with another distributive justice principle. Furthermore, basing a decision primarily upon merit, which may arise in part due to unequal environments and unremedied needs earlier in life, also brings the admissions process into conflict with the distributive justice principle of need as well as equality.

Justice principles also come into play in connection with public acceptance of governmental decision-making. Arvai (2003) found that when members of the public were told that a governmental decision had been made with public participation, they were more likely to approve of the actual decision, a finding that is consistent with Tyler's views of the intersection between procedural justice and legitimacy of governmental decision-making (e.g., Tyler, 2000, 2006; Tyler \& Darley, 2000). Arvai's study looked at public reactions to a governmental decision in the context of a risk communication by the National Aeronautics and Space Administration (NASA) and the Jet Propulsion Laboratory (JPL) 
with regard to a space mission. One central issue in the risk communication was the decision by mission planners to include generators containing approximately 33 kilograms of plutonium for generating spacecraft electricity. The decision was considered a controversial one due to the dangerous nature of the radioactive fuel when it appeared that other non-nuclear options were available, and while NASA and the JPL took several steps to help minimize the risk to civilians and the environment, there was considerable protest in the time leading up to the mission launch.

The Arvai study provided participants with one of two sets of documents describing the mission. Both documents included language developed by NASA and JPL to discuss the risk of the nuclear fuel on the mission. However, one version of the fact sheet indicated that the decision had involved "joint discussions and careful planning among experts in the North American and European space program," while the other included the following language:

Planning for this mission was one of the firsts of its kind to involve active participation from the public as well as experts. All of the parties, expert and public alike, involved in mission planning were treated equally by the International Space Consortium in terms of their values and objectives for a safe and productive mission ( $\mathrm{p}$. 283).

Participants were asked to respond to a variety of questions, some of which were designed to assess their opinions about both the decision to proceed with the space mission (decision-making outcome) and the process used to arrive at that decision and whether that process made them more or less likely to support the overall decision. Participants were more likely to support the mission in the public involvement condition than in the expert-only condition. Similarly, participants were more satisfied with the decision-making process in the public involvement condition than in the expert-only condition. The author concluded that the use of participatory decision-making processes - that is, those that provide an opportunity for public voice, a procedural justice concern - conferred greater legitimacy upon governmental decisions than an expert-only decision-making process.

In another study examining the effects of justice constructs outside of the courtroom context, Hopkins and Weathington (2006) recently looked at the influence of distributive and procedural justice principles and their interaction, along with other factors, in downsizing situations in the corporate workplace. Their research focused on the survivors of the downsizing - that is, those who remained employed at the workplace following a round of layoffs. Noting earlier research by McFarlin and Sweeny (1992), which had concluded that employee perceptions of procedural justice in the workplace were a predictor of organizational commitment and trust in the organization, Hopkins and Weathington found significant relationships between both distributive justice and procedural justice, coupled with trust, on the one hand, and factors like organizational satisfaction, affective commitment, and turnover intentions (i.e., intent to seek employment elsewhere), on the other hand. 


\section{Conclusion}

Decisions made between competing parties and among various options are a daily fact of life across the societal spectrum: Businesses decide which projects to allocate resources to, parents decide appropriate rewards and punishments for their children, employers resolve disputes between employees or with their customers, health maintenance organizations decide how to spend limited financial resources to try to obtain the best overall results for their covered enrollees (usually while attempting to maintain profitability), federal, state and local governments make resource allocation determinations, and so forth. Procedural and distributive justice principles, and possibly even restorative and retributive justice principles, are implicated in all of these instances, and thus provide fertile ground for future inquiry by behavioral science researchers interested in expanding their research outside of the courtroom context.

In conclusion, while government, business, education, and many other spheres of civil society that raise justice concerns touch on the law and are impacted by the courts, they nonetheless operate primarily outside the litigation context, exercising enormous influence on human behavior. Psycholegal scholars should consider devoting more time and resources to studying justice issues in these contexts. We have long known the threat of judge or jury decision-making facilitates dispute resolution (e.g., Mnookin \& Kornhauser, 1979), but we know much less about why it is the case that the vast majority of disputes are resolved without any recourse to the formal legal system. There is much to know. Whether the matter is as potentially mundane as teenager compliance with school rules, as nationally imperative as health care or economic reforms (e.g., Smith \& Tyler, 1996), or as wrenching as the debate about the appropriate forums to resolve claims and the compensation amounts to be paid to the victims of the September 11th terrorist attacks (e.g., Bornstein \& Poser, in press; Tyler \& Thorisdottir, 2003), justice constructs can assist in social scientific understanding of the vast array of differences that arise in modern-day, diverse civil society (e.g., Tyler, 1994a, 2000; Tyler, Lind, \& Huo, 2000).

\section{References}

Adams, J. S. (1965). Inequity in social exchange. In L. Berkowitz (Ed.), Advances in experimental social psychology (Vol. 2, pp. 267-299). New York: Academic Press.

Arvai, J. L. 2003. Communicating the results of participatory decision making: Effects on the perceived acceptability of risk-policy decisions. Risk Analysis, 23, 281-291.

Bornstein, B. H., \& Poser, S. (in press). Perceptions of procedural and distributive justice in the September 11th Victim Compensation Fund. Cornell Journal of Law and Public Policy.

Brickman, P. (1977). Crime and punishment in sports and society. Journal of Social Issues, 33(1), 140-164.

Court Statistics Project. (2006). State court caseload statistics, 2005. Williamsburg, VA: National Center for State Courts; http://www.ncsconline.org/D_Research/csp/2005 files/State\%20Court\%20Caseload\%20Statistics\%202005.pdf 
Cross, F. B. (2005). Law and trust. Georgetown Law Review, 93, 1457-1545.

Deutsch, M. (1985). Distributive justice: A social-psychological perspective. New Haven: Yale University Press.

Elster, J. (1995). The idea of equality revisited. In J. Altham and R. Harrison (Eds.), World, mind, and ethics: Essays on the ethical philosophy of Bernard Williams (pp. 4-18). New York: Cambridge University Press.

Felstiner, W. L. F., Abel, R. L., \& Sarat, A. (1980-1981). The emergence and transformation of disputes: Naming, blaming, claiming. Law and Society Review, 15, 631-655.

Galanter, M. S. (1983). Reading the landscape of disputes: What we know and don't know (and think we know) about our allegedly contentious and litigious society. UCLA Law Review, 31, 4-71.

Galanter, M. S. (1993). News from nowhere: The debased debate on civil justice. Denver University Law Review, 71, 77-103.

Galanter, M. S. (1996). Real world torts: An antidote to anecdote. Maryland Law Review, 55, 1093-1160.

Gray-Kanatiiosh, B., \& Lauderdale, P. (2006). The web of justice: Restorative justice has presented only part of the story. Wicazo Sa Review, 21(1), 29-41.

Greene, E. (2007). "Can we talk?" Therapeutic jurisprudence, restorative justice, and tort litigation. In B. H. Bornstein et al. (eds.), Civil Juries and Civil Justice. New York: Springer.

Hegtvedt, K. A., \& Cook, K. S. (2001). Distributive justice: Recent theoretical developments and applications. In J. Sanders \& V. L. Hamilton (Eds.), Handbook of justice research in law (pp. 93-132). New York: Kluwer Academic/Plenum Publishers.

Helm, J. P. (2001). Asbestos litigation and the proposed administrative remedy: Between the values of individualism and distributive justice. Emory Law Journal, 50, 631-662.

Hersch, J. (2006). Demand for a jury trial and the selection of cases for trial. Journal of Legal Studies, 35, 119-142.

Hibbing, J. R., \& Theiss-Morse, E. (Eds.) (2001). What is it about government that Americans dislike? New York: Cambridge University Press.

Hopkins, S. M., \& Weathington, B. L. (2006). The relationships between justice perceptions, trust, and employee attitudes in a downsized organization. Journal of Psychology: Interdisciplinary and Applied, 140, 477-498.

Kritzer, H. M., Vidmar, N., \& Bogart, W. A. (1991). To confront or not to confront: Measuring claiming rates in discrimination grievances. Law and Society Review, 25, 875-887.

Lerner, M. J. (1975). The justice motive in social behavior: Introduction. Journal of Social Issues, 31(3), 1-19.

Lerner, M. J., \& Lerner, S. C. (Eds.) (1981). The justice motive in social behavior: Adapting to times of scarcity and change. New York: Plenum.

Lind, E. A., \& Tyler, T. R. (1988). The social psychology of procedural justice. New York: Plenum Press.

Markell, D. L. (2006). Understanding citizen perspectives on government decision making processes as a way to improve the administrative state. Environmental Law, 36, 651-708.

McFarlin, D. B., \& Sweeney, P. D. (1992). Distributive and procedural justice as predictors of satisfaction with personal and organizational outcomes. Academy of Management Journal, 35, 626-637.

Michelbach, P. A., Scott, J. T., Matland, R. E., \& Bornstein, B. H. (2003). Doing Rawls justice: An experimental study of income distribution norms. American Journal of Political Science, $47,523-539$. 
Miller, R. E., \& Sarat, A. (1980-1981). Grievances, claims, and disputes: Assessing the adversary culture. Law and Society Review, 15, 525-566.

Mnookin, R. H., \& Kornhauser, L. (1979). Bargaining in the Shadow of the Law: The Case of Divorce, Yale Law Journal, 88, 950-997.

Morrison, B., \& Ahmed, E. (Eds.) (2006). Restorative justice and civil society. Journal of Social Issues, 62 (2), 209-438.

Pleasence, P. (2006). Causes of action: Civil law and social justice (2nd ed.). Norwich, England: The Stationary Office and Legal Services Commission.

Robbennolt, J. K. (2003). Apologies and legal settlement. Michigan Law Review, 102, 461-516.

Robbennolt, J. K. (2005). What we know and don't know about the role of apologies in health care disputes. Georgia State University Law Review, 21, 1009-1027.

Robbennolt, J. K. (2006). Apologies and settlement levers. Journal of Empirical Legal Studies, 3, 333-373.

Robbennolt, J. K. (2007). Apologies and civil justice. In B. H. Bornstein et al. (eds.), Civil Juries and Civil Justice. New York: Springer.

Roche, D. (2006). Dimensions of restorative justice. Journal of Social Issues, 62(2), 217-238.

Rubin, E. (2005). The myth of accountability and the anti-administrative impulse. Michigan Law Review, 103, 2073-2136.

Scott, J. T., Matland, R. E., Michelbach, P. A., \& Bornstein, B. H. (2001). Just deserts: An experimental approach to distributive justice. American Journal of Political Science, 45, 749-767.

Shultz, T. R., \& Darley, J. M. (1991). An information-processing model of retributive justice based on "legal reasoning". In W. M. Kurtines \& J. L. Gewirtz (Eds.), Handbook of moral behavior and development: Research (Vol. 2, pp. 247-278). Hillsdale, NJ: Erlbaum.

Smith, H. J., \& Tyler, T. R. (1996). Justice and power: Can justice motivations and superordinate categorizations encourage the advantaged to support policies which redistribute economic resources and encourage the disadvantaged to willingly obey the law? European Journal of Social Psychology, 26, 171-200.

Suk, J. C. (2006). Antidiscrimination law in the administrative state. University of Illinois Law Review, 2006, 405-473.

Thibaut, J. W., \& Kelley, H. H. (1959). The social psychology of groups. New York: John Wiley.

Thibaut, J., \& Walker, L. (1975). Procedural justice: A psychological analysis. Hillsdale, NJ: Erlbaum.

Thibaut, J., \& Walker, L. (1978). A theory of procedure. California Law Review, 66, 54166. Trubek, D. M., Grossman, J. B., Felstiner, W. L. F., Kritzer, H. M., \& Sarat, A. (1983). Civil litigation research project: Final report. Madison: University of Wisconsin Law School.

Trubek, D. M., Sarat, A., Felstiner, W. L. F., Kritzer, H. M., \& Grossman, J. B. (1983). The costs of ordinary litigation. UCLA Law Review, 31, 72-127.

Tyler, T. R. (1988). What is procedural justice?: Criteria used by citizens to assess fairness in legal procedures. Law and Society Review, 22, 103-135.

Tyler, T. R. (1991). Using procedures to justify outcomes: Testing the viability of a procedural justice strategy for managing conflict and allocating resources in work organizations. Basic and Applied Social Psychology, 12, 259-279.

Tyler, T. R. (1992). The psychological consequences of judicial procedures: Implications for civil commitment hearings. Southern Methodist University Law Review, 46, 401-413. 
Tyler, T. R. (1994a). Governing amid diversity: Can fair decision-making procedures bridge competing public interests and values? Law and Society Review, 28, 701-722.

Tyler, T. R. (1994b). Psychological models of the justice motive. Journal of Personality and Social Psychology, 67, 850-863.

Tyler, T. R. (1997b). The psychological of legitimacy: A relational perspective on voluntary deference to authorities. Personality and Social Psychology Review, 1, 323-345.

Tyler, T. R. (2000). Social justice: Outcome and procedure. International Journal of Psychology, 35, 117-125.

Tyler, T. R. (2004). Affirmative action in an institutional context: The antecedents of policy preferences and political support. Social Justice Research, 17, 5-24.

Tyler, T. R. (2006b). Restorative justice and procedural justice: Dealing with rule breaking. Journal of Social Issues, 62(2), 307-326.

Tyler, T. R. (2007). Racial profiling, attributions of motive, and the acceptance of social authority. In R. L. Wiener, B. H. Bornstein, R. Schopp, \& S. L. Willborn (Eds.), Social consciousness in legal decision making: Psychological perspectives (pp. 61-74). New York: Springer.

Tyler, T. R., Boeckmann, R. J., Smith, H. J., \& Huo, Y. J. (1997). Social justice in a diverse society. Boulder, CO: Westview Press.

Tyler, T. R., \& Darley, J. (2000). Building a law-abiding society: Taking public views about morality and the legitimacy of legal authorities into account when formulating substantive law. Hofstra Law Review, 28, 707-739.

Tyler, T. R., \& Lind, A. E. (2001). Procedural justice. In J. Sanders and V. L. Hamilton (Eds.), Handbook of justice research in law (pp. 65-92). New York: Kluwer Academic/Plenum Publishers.

Tyler, T. R., Lind, E. A., \& Huo, Y. J. (2000). Cultural values and authority relations. Psychology, Public Policy, and Law, 6, 1138-1163.

Tyler, T. R., \& Thorisdottir, H. (2003). A psychological perspective on compensation for harm: Examining the September 11th Victim Compensation Fund. DePaul Law Review, 53, 355-391.

Umbreit, M. S., \& Ritter, R. (2006). Arab offenders meet Jewish victim: Restorative family dialogue in Israel. Conflict Resolution Quarterly, 24, 99-109.

Umbreit, M. S., Vos, B., Coates, R. B., \& Lightfoot, E. (2006). Restorative justice in the twenty-first century: A social movement full of opportunities and pitfalls. Marquette Law Review, 89, 251-304.

U.S. Courts. (2007, March 13). Fiscal year 2006 caseloads remain at high levels. Online at http://www.uscourts.gov/Press_Releases/caseload031307print.html

Vines, P. (2007). The power of apology: Mercy, forgiveness or corrective justice in the civil liability arena? Public Space: The Journal of Law and Social Justice, 1 (1), Art. 5, 1-51; http://epress.lib.uts.edu.au/ojs/index.php/publicspace/article/viewFile/535/482

Walster, E., Walster, G. W., \& Berscheid, E. (1978). Equity: Theory and research. Boston: Allyn \& Bacon.

Weinrib, E. J. (2002). Corrective justice in a nutshell. University of Toronto Law Journal, 52, 349-356. 